\title{
Plant parasitic nematode survival and detection to inform biosecurity risk assessment
}

\author{
Lee T. Aalders ${ }^{1,3}$, Mark R. McNeill',3, Nigel L. Bell ${ }^{1,3}$, Catherine Cameron' \\ I AgResearch, Ruakura Research Centre, Private Bag 3123, Hamilton 3240, New Zealand 2 AgResearch, \\ Lincoln, Private Bag 4749, Canterbury 8140, New Zealand 3 Better Border Biosecurity \\ Corresponding author: Lee T. Aalders (lee.aalders@agresearch.co.nz)
}

Academic editor: R. Shaw | Received 7 December 2016 | Accepted 23 May 2017 | Published 26 June 2017

Citation: Aalders LT, McNeill MR, Bell NL, Cameron C (2017) Plant parasitic nematode survival and detection to inform biosecurity risk assessment. NeoBiota 36: 1-16. https://doi.org/10.3897/neobiota.36.11418

\begin{abstract}
Plant parasitic nematodes (PPN) are known to survive periods of desiccation, an ability that increases the risk of them surviving unintentional transport between countries. To investigate nematode survival in soil subject to prolonged storage, soil collected from a native forest and an organic orchard was stored separately in cupboards at ambient temperature for 36 months. Subsamples were taken at $0,3,6,12,13,24$ and 36 months to determine the presence of plant parasitic and total nematodes using a standard misting technique. Pratylenchus was used as a model to determine if PPNs that had been under prolonged storage were able to infect plant hosts at 13,24 and 36 months.

Overall, the total number of nematodes recovered from stored soil declined over time, with differences in species diversity determined by molecular methods, related to soil origin. No PPN were recovered in soil stored beyond 13 months using the three-day misting technique. By comparison, Pratylenchus nematodes, using a baiting method, were found to successfully invade host plant roots (ryegrass and white clover) even after 36 months storage and were observed to produce offspring at 13 months. Baiting was not effective for Pratylenchus found in soil originally collected from the forest but was for orchard soil, a result attributed to the lack of suitable host plants for the Pratylenchus species found in forest soil.

This study demonstrated, that in protected environments, nematodes could survive for at least 36 months and were observed to produce offspring at 13 months. Baiting with a host plant was more sensitive in detecting nematodes than using the misting extraction technique, although this approach only works where the host plant is known. Without a priori knowledge of the nematode-plant host association, plant baiting may also produce false negatives. In the context of plant biosecurity and providing an accurate risk assessment in soil contaminants, the development of a generic test for PPN that induces nematodes in a resting stage to emerge and respond to a cue would enhance the probability of detection. However, as assessments at the border are often time limited, a molecular based bioassay that can be used to indicate the presence of multiple species of live PPN species may be a more feasible option for risk assessments.
\end{abstract}

Copyright Lee T.Aalders et al. This is an open access article distributed under the terms of the Creative Commons Attribution License (CC BY 4.0), which permits unrestricted use, distribution, and reproduction in any medium, provided the original author and source are credited. 


\section{Keywords}

invasion pathways, soil risk, plant biosecurity, screening tool, international trade, molecular diagnostics, invasive pests

\section{Introduction}

Trade and tourism are important to the economic wellbeing of the world's global economy, but carry with it the real risk of introducing unwanted organisms that threaten the productive sectors of individual countries or regions because of production losses due to direct yield reduction or cost for pest control (Mack et al. 2000, Pimentel et al. 2000, Work et al. 2005, Hulme 2014). For natural habitats and native biota, invasive species can have both direct and indirect impacts through modification, displacement or eradication costs along with a general loss of biodiversity (Lee and Lee 2015). Impacts can therefore be economic, ecological and social with the impacts and costs prolonged for intractable invasive species. Plant parasitic nematodes (PPN) are estimated to cause billions of dollars (USD) of crop damage worldwide each year, many of which have known or potential phytosanitary importance (Singh et al. 2013).

Amongst PPNs there are three main types of parasitism, ectoparasitic, endoparasitic and semi-endoparasitic (Decraemer and Hunt 2006). For ectoparasites (e.g. Paratylenchus, Criconematidae), the nematodes remain within the soil feeding externally on plant roots. Two types of endoparasites feed within the roots; there are migratory ones such as Pratylenchus which do not form a permanent feeding site and can move in and out of the plant; and sedentary ones such as Globodera and Heterodera which form a permanent feeding site except for the infective second stage juveniles which are mobile within the soil. For semiendoparasites, such as Helicotylenchus, only the anterior portion of the nematode penetrates the root with the posterior portion remaining in the soil (Decraemer and Hunt 2006).

While their minute size and cryptic nature in plants and soil makes discovery more difficult when transported, the ability of many PPN species to survive periods of desiccation (Norton 1978), makes these nematodes a biosecurity issue as it increases the probability of establishment when inadvertently transported from one country to another via trade and tourism routes. PPNs have been detected in soil associated with shipments of imported seeds (Lal and Lal 2006), plant material (Tenente et al. 1996), contaminated footwear (McNeill et al. 2011), used machinery (Hughes et al. 2011, Aalders et al. 2012) and sea containers (Gadgil et al. 2000, McNeill et al. unpublished data).

In an effort to improve predictions on which PPN species will become invasive in a country or region before they arrive, a Pest Screening and Targeting (PeST) framework has been developed to provide a more structured and systematic approach for screening large numbers of species and identifying species likely to become invasive (Singh et al. 2015). PeST integrates heterogeneous information and data on species biogeography, biotic and abiotic factors to first determine a preliminary risk index. While species with better survival adaptations pose greater risks than those without the capability, a 
paucity of information on survival in transit represents an important knowledge gap when developing a pest risk profile for PPNs (Singh et al. 2015).

In this current study, soil was collected and stored in cupboards to mimic soil contaminants that may be stored in a protected environment (e.g. contaminated footwear, used equipment or camping gear) for a period of time before reuse. The study assessed not only nematode survival but the viability of nematodes recovered from soil that had been stored in a cupboard over a 36 month period. While the research commenced prior to the development of the PeST framework proposed by Singh et al (2015), this work provides a valuable contribution to our understanding of nematode survival over time. The hypothesis tested was that nematodes surviving long term desiccation would be able to subsequently invade plant roots ('baiting'), thus presenting a heightened biosecurity risk.

\section{Methods}

\section{Collection and processing of soil}

Soil was collected in late winter (23 August 2011) from two sites in the Canterbury region of New Zealand; a native forest reserve in Prices Valley, Banks Peninsula (S43.7669, E172.7140) and an organic orchard at Lincoln (S43.6508; E172.4559). At each site, a spade square soil sample $(140 \mathrm{~mm} \times 140 \mathrm{~mm})$ was taken to a depth of $5 \mathrm{~cm}$ at three randomly chosen points within a $3 \mathrm{~m}$ radius of an arbitrarily designated central point. The soil sampled from these three locations at each site were treated separately throughout the experiment. Any vegetation was cut to ground level with scissors and loose litter was removed from the sample point prior to collection. The individual soil samples were mixed separately in a stainless steel tray and transferred to a plastic bag. The spade was cleaned with 70\% ethanol between each site and location. Disposable laboratory gloves were worn at all times, and changed between sites. The work presented in this paper is part of a project published in McNeill et al. (2017), methods for collecting and processing the soil are the same as described in that paper.

In the laboratory, the soil was sieved (10 $\mathrm{mm}$ sieve) and a subsample taken for nematode counts and identification. The remaining soil from each site and sampling location (six individual soil sources) was divided amongst stainless steel steam trays (dimensions c. $400 \times 200 \times 50 \mathrm{~mm}(300 \mathrm{~mm} \times 240 \mathrm{~mm}$ internal dimensions)), in which twenty $\times 4 \mathrm{~mm}$ drainage holes had been drilled into the base, then allocated to treatments (c. $700 \mathrm{~g}$ of soil per tray). The soil was spread roughly evenly onto the tray surface and gently pressed with a stainless steel pan to lightly compact the soil, resulting in a soil depth of approximately $40 \mathrm{~mm}$ (McNeill et al. 2017). Soil from all sites contained plant root material.

The uncovered tray was then placed within a cupboard situated indoors at ambient temperature at Lincoln (S43.6279, E172.4704). The soil in the trays was subsampled at 3, 6, 12, 13, 24 and 36 months. Approximately $75 \mathrm{~g}$ soil was collected from each tray using a stainless steel spoon and placed in a $100 \mathrm{ml}$ plastic screw cap container. The spoon was cleaned with $70 \%$ ethanol between sampling each tray. 
In addition to the above, the two original locations were resampled at 3, 6, 12, 13, 24 and 36 months. This was to monitor the natural population in relation to counts taken from the stored soil to ensure that any decrease in population was due to storage. As per the original sampling strategy, at the three locations within each of the two original sites, soil was collected using $20 \times 25 \mathrm{~mm}$ diameter $\times 100 \mathrm{~mm}$ deep cores, hand crumbled and mixed.

\section{Extraction methodology}

There are a range of accepted nematode extraction techniques (Hooper 1986, Hooper and Evans 1993, Hunt and De Ley 1996). Techniques are classified as either active methods such as the Whitehead and Hemming tray and misting, or passive such as centrifugation and flotation - sieving (McSorley and Walter 1991, Hooper and Evans 1993, Hunt and De Ley 1996). The misting method was chosen because it provided the capability for high throughput of the large number of samples. The limitation was that the method would not have extracted nematode cysts, but was the most efficient and cost effective method available.

\section{Nematode survival and viability}

To determine nematode survival over the duration of the study, at each storage time, a $25 \mathrm{~g}$ soil subsample was placed in a mistifier funnel for extraction and misted for $30 \mathrm{sec}$ every $5 \mathrm{~min}$ over 72 hours at a water temperature of $20^{\circ} \mathrm{C}$. The water from the mister flushes the nematodes through the soil and into a test tube where they are collected. For the original day zero samples $100 \mathrm{~g}$ of fresh soil was placed on to extraction trays (Bell and Watson 2001) and extracted over a $72 \mathrm{hr}$ period. At the three month sampling time the two methods of extraction were compared and no significant difference found (data unpublished). For the 36 month bioassay, samples were extracted for an additional 48 hours, in the expectation that prolonged storage could result in poor physiological condition so that more time may be required to extract surviving nematodes. Counts were taken for all nematodes (bacterivores, fungivores, omnivores, predators and plant parasites); PPNs were identified to genera where possible.

The endoparasitic nematode Pratylenchus was the only nematode extracted from soil after 12 months, so at 13, 24 and 36 months, the ability of Pratylenchus to invade plant roots was tested using both white clover (Trifolium repens $\mathrm{L}$.) and ryegrass (Lolium spp.) as bait plants. To determine viability, plastic pots $(50 \mathrm{~mm} \times 50 \mathrm{~mm} \times$ $120 \mathrm{~mm}$ ), were part filled with $140 \mathrm{~g}$ of oven dried sand and topped with $46 \mathrm{~g}$ of soil from each ca. $75 \mathrm{~g}$ sample. The six original sites were also sampled to check plant host suitability of the sown seed for the nematode species present. This resulted in 24 pots of cupboard soil and 12 pots of fresh soil collected from the original six sites. Each pot was sown with three nil-endophyte ryegrass Lolium multiflorum (cv. Moata for 
2012) and L. perenne (cv. Samson for 2013 and 2014) and 6-8 white clover Trifolium repens (cv. Sustain) seeds. The pots were randomised, placed into two forestry crates, maintained in a $20^{\circ} \mathrm{C}$ controlled environment room with a light: dark photoperiod of 16: 8 hours and watered as required. The forestry crates enabled the pots to be held separately from each other and above the bench to avoid cross contamination.

Twenty four days post-sowing, the ryegrass and white clover seedlings were removed from each pot, gently washed to remove adhering soil and counted before the shoots and roots were separated and weighed. For each pot, ryegrass and white clover roots were stained using aniline blue (Rohan et al. 2006), to determine if Pratylenchus nematodes had infected the seedling roots.

\section{Molecular identification of PPNs}

DNA was extracted from single nematode specimens using the prepGEM ${ }^{\mathrm{TM}}$ tissue kit (ZyGEM Corporation Ltd, New Zealand) according to manufacturer's instructions.

DNA was amplified in $25 \mu \mathrm{l}$ reactions using $1 \mathrm{x}$ buffer (Thermo Scientific Finnzymes), $0.2 \mathrm{mM}$ dNTPs, $0.3 \mu \mathrm{M}$ of each primer, $0.2 \mathrm{mg} / \mathrm{ml} \mathrm{BSA}$ and 0.5 units of Phusion Hot Start II Hi-Fi DNA polymerase (Thermo Scientific Finnzymes). Thermo cycling included an initial denaturing at $98{ }^{\circ} \mathrm{C}$ for $2 \mathrm{~min}$, then 40 cycles of $98^{\circ} \mathrm{C}$ for $10 \mathrm{sec}, 57^{\circ} \mathrm{C}$ for 30 seconds, and $72{ }^{\circ} \mathrm{C}$ for $60^{\circ} \mathrm{C}$, with a final extension step of $72{ }^{\circ} \mathrm{C}$ for 5 minutes. The product was purified using the GeneJET PCR Purification Kit (Thermo Scientific ${ }^{\mathrm{TM}}$ ). The fragments were sequenced by Massey Genome Service (Massey University, New Zealand) and cleaned using the computer programme Geneious ${ }^{\mathrm{TM}}$ 8.1.5 (Kearse et al. 2012). The sequences were compared to nematode sequences in the BLAST (Basic Local Alignment Search Tool) database (http://www.ncbi.nlm.nih.gov/blast.cgi).

Restriction fragment length polymorphism analysis (RFLPs) of the internal transcribed spacer (ITS) regions of ribosomal DNA was used to try and distinguish between the closely related Heterodera species to identify the Heterodera specimen isolated from the orchard soil in this study. Three reference sequences for each of $H$. trifolii, $H$. schachtii and $H$. betae were imported into Geneious to compare. In silico, the restriction enzyme MspI generated a RFLP profile that showed the

Table I. The primers used for sequencing of the plant parasitic nematodes.

\begin{tabular}{|c|c|c|c|}
\hline Nematode taxa & Primer code & $\begin{array}{c}\text { Amplified region of the } \\
\text { rDNA gene }\end{array}$ & Reference \\
\hline Criconematidae & SSU_F_07 / 18P & $18 \mathrm{~S}$ & (Blaxter et al. 1998) \\
\hline Globodera / Heterodera & TW81/AB28 & ITS1 - 5.8S - ITS2 & (Joyce et al. 1994) \\
\hline $\begin{array}{l}\text { Paratylenchus I } \\
\text { Pratylenchus I } \\
\text { Helicotylenchus I } \\
\text { Rotylenchus }\end{array}$ & $\mathrm{D} 2 \mathrm{~A} / \mathrm{D} 3 \mathrm{~B}$ & D2 - D3 segment of the $28 \mathrm{~S}$ & (De Ley et al. 1999) \\
\hline
\end{tabular}


sequence of this Heterodera nematode was not $H$. schachtii, but did not distinguish $H$. trifolii from $H$. betae. $H$. trifolii is widespread throughout New Zealand while $H$. betae has not been described from New Zealand.

\section{Soil Moisture}

To determine soil moisture at the 6 and 12 month bioassay, a separate $20 \mathrm{~g}$ sub-sample of soil was taken from each sample and oven dried at $80{ }^{\circ} \mathrm{C}$ for 48 hours. The availability of the remaining soil was limited at 13, 24 and 36 months, so soil moisture was determined using the $25 \mathrm{~g}$ of soil following processing in the mistifier funnel. As with the earlier samples, the soil was oven dried at $80{ }^{\circ} \mathrm{C}$ for 48 hours.

Temperature and humidity in the cupboards was measured using a Tinytag Ultra Temperature/Humidity logger (Gemini Data Loggers (UK) Ltd.).

\section{Analysis}

Data was analysed by split plot analysis of variance using GenStat (16th edition). Soil samples were the main plots and replicate trays the sub plots. Nematode data were log transformed to equalize the variance to better meet the normality assumptions of the analysis.

\section{Results}

Temperature and humidity in the cupboards averaged $12.5^{\circ} \mathrm{C}$ (range $0.8-25.9{ }^{\circ} \mathrm{C}$ ) and $76.9 \%$ (38.4-100\%), respectively, over the course of the 36 month experiment. Soil moisture at the beginning of the experiment (day zero) was 34-38 \% and 30-32 $\%$ for the forest and orchard soils respectively. At 13 months, the forest soil moisture ranged from $4.2-4.6 \%$ compared to $3.3-3.5 \%$ for the orchard soil $(\mathrm{P}<0.001)$, with no significant change in moisture content from 13 to 36 months.

\section{Total nematode numbers}

The total number of nematodes extracted from the freshly collected forest and orchard soils was variable within each site (mean of 37.9 and $43.4 / \mathrm{g}$ dry soil for forest and orchard, respectively), but with no significant difference between the two sites or the six different sampling times (Figure 1).

By comparison, for the stored samples, there was a difference between soil origin with the forest soil having significantly less nematodes than the orchard soil at $6,12,13$ and 24 months $(\mathrm{P}<0.001)$ storage. After 36 months of storage, nematodes were only extracted from one sample and that was from orchard soil (1 of 12 trays) (Figure 1). 


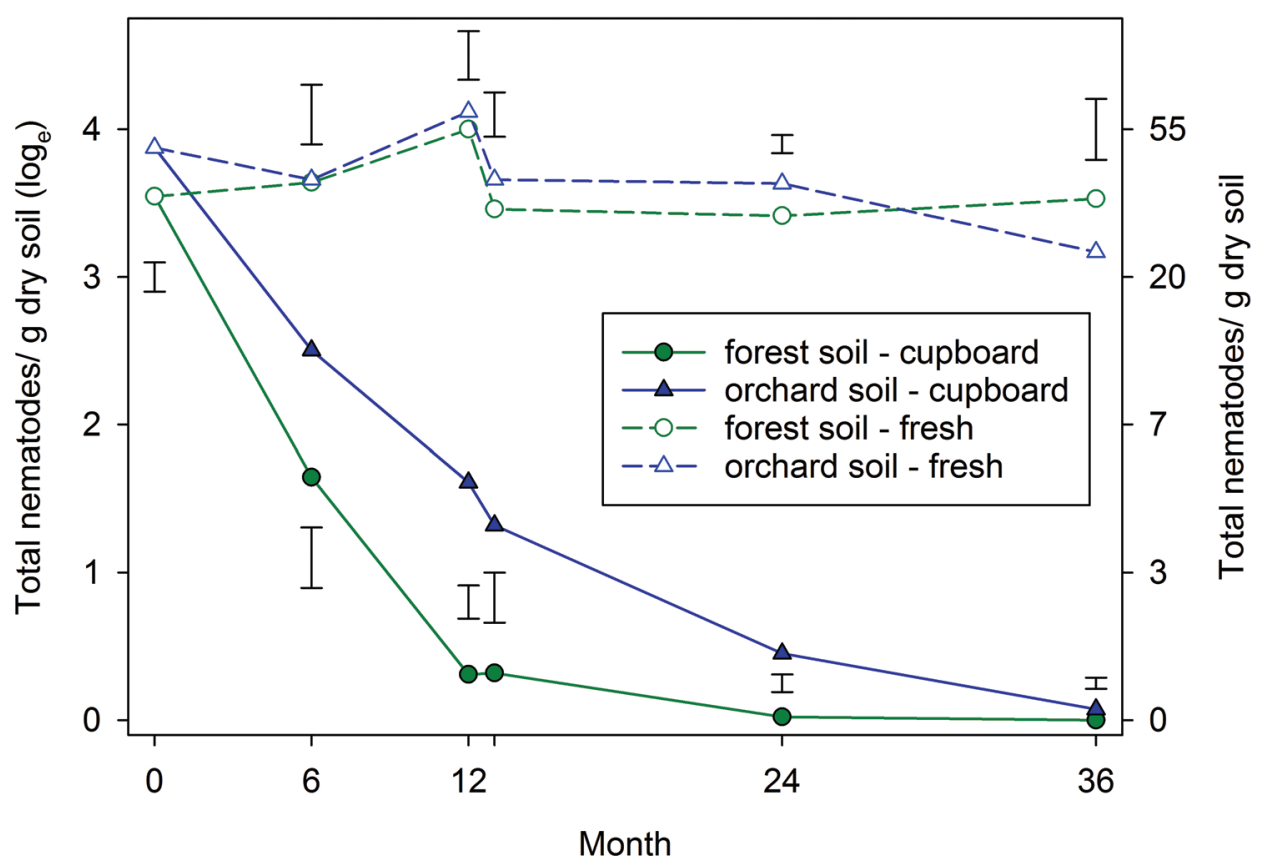

Figure I. Mean total number of nematodes per gram of dry soil ( $\log _{\mathrm{e}}$ transformed) collected from either forest or orchard and stored in cupboards for up to 36 months or freshly collected from the original sites. Error bars are SEDs. Note: transformed data presented with back-transformed scale on right hand side for ease of conversion to actual numbers $/ g$.

\section{Plant parasitic nematodes}

Fresh soil collected from the forest site contained the highest diversity of plant parasitic genera with a mean/g of dry soil of 1.9 Pratylenchus, 2.3 Paratylenchus, 0.3 Globodera, 0.3 Helicotylenchus / Rotylenchus and 0.1 for Criconematidae. By comparison, in the orchard soils, the plant parasitic genera consisted of 1.5 Pratylenchus, 1.8 Paratylenchus and 0.1 Heterodera spp. / g dry soil from the orchard site.

Over all sample times, Pratylenchus comprised $4.4 \%$ and $10.4 \%$ of the total nematode fauna in the forest and orchard soils, respectively. PPN populations were substantially larger in the fresh soil than were observed in stored soil (results not shown), especially so for the orchard samples.

\section{Stored samples}

Of the PPN taxa recovered at three months, Pratylenchus was the most common, found in seven of the twelve forest soil samples $(58 \%)$ and in all of the orchard samples (12/12) (Table 2). Small numbers of Paratylenchus, Globodera, Helicotylenchus / Rotylenchus and Criconematidae were also recovered from the forest soil at three months. 
Table 2. Age of soil from which plant parasitic nematode taxa were extracted using the three day misting technique, from $25 \mathrm{~g}$ of soil collected from either the forest or orchard location and stored in cupboards for 36 months.

\begin{tabular}{l|c|c|c|c}
\hline \multirow{2}{*}{} & \multicolumn{4}{c}{ Months } \\
\cline { 2 - 5 } & $\mathbf{3}$ & $\mathbf{6}$ & $\mathbf{1 2 / 1 3}$ & $\mathbf{2 4 - 3 6}$ \\
\hline Forest & Present & Present & & \\
\hline Pratylenchus & Present & & & \\
\hline Paratylenchus & Present & & & \\
\hline Globodera & Present & & & \\
\hline Helicotylenchus/Rotylenchus & Present & Present & & \\
\hline Criconematidae & Present & & & \\
\hline Orchard & Present & Present & Present & \\
\hline Heterodera & \multicolumn{5}{|l}{} & \\
\hline Pratylenchus & Pratylenchus & & & \\
\hline
\end{tabular}

Heterodera were present in very low numbers from the orchard site, with 1-10 nematodes extracted at the 3 month sampling (3/12 samples) despite none being extracted from the original sample (day zero). At six months, with the exception of a single Criconematidae from the forest soil and two Paratylenchus nematodes from the orchard soil, Pratylenchus was the only plant parasitic nematode extracted (Table 2). At both the 12 and 13 month sampling, the only PPN recovered were Pratylenchus spp.

Thirteen months after soil had been placed into cupboards, Pratylenchus were the only PPN recovered using the misting technique, and then only from the orchard soil. Of those recovered, both female and juvenile stages were present.

The number of Pratylenchus recovered over time decreased substantially using a three day misting interval for extraction, with no specimens detected from soil stored for 24 and 36 months (Figure 2). An extra two days extraction time at 36 months did result in three Pratylenchus nematodes from one sample, all three of which were females.

\section{Plant baiting}

Sowing white clover and ryegrass seed resulted in Pratylenchus being recovered from more samples than with mistifier extraction at the 13, 24 and 36 month sampling intervals. At 13 months, Pratylenchus were found in four root samples (4 of 12 samples, 33\%), but not in their respective misting samples. At 24 months, Pratylenchus were detected in five root samples (42\%) and at 36 months in three samples (25\%).

Reproductively mature Pratylenchus were evident in soil that had been stored for 13 months with eggs observed in white clover plant roots from two (c. 17\%) of the stored orchard soil samples, demonstrating that not only could these nematodes survive in stored soil without a host plant but could also subsequently infect and reproduce in plant roots. No other PPN genera were detected using the plant baiting method. 


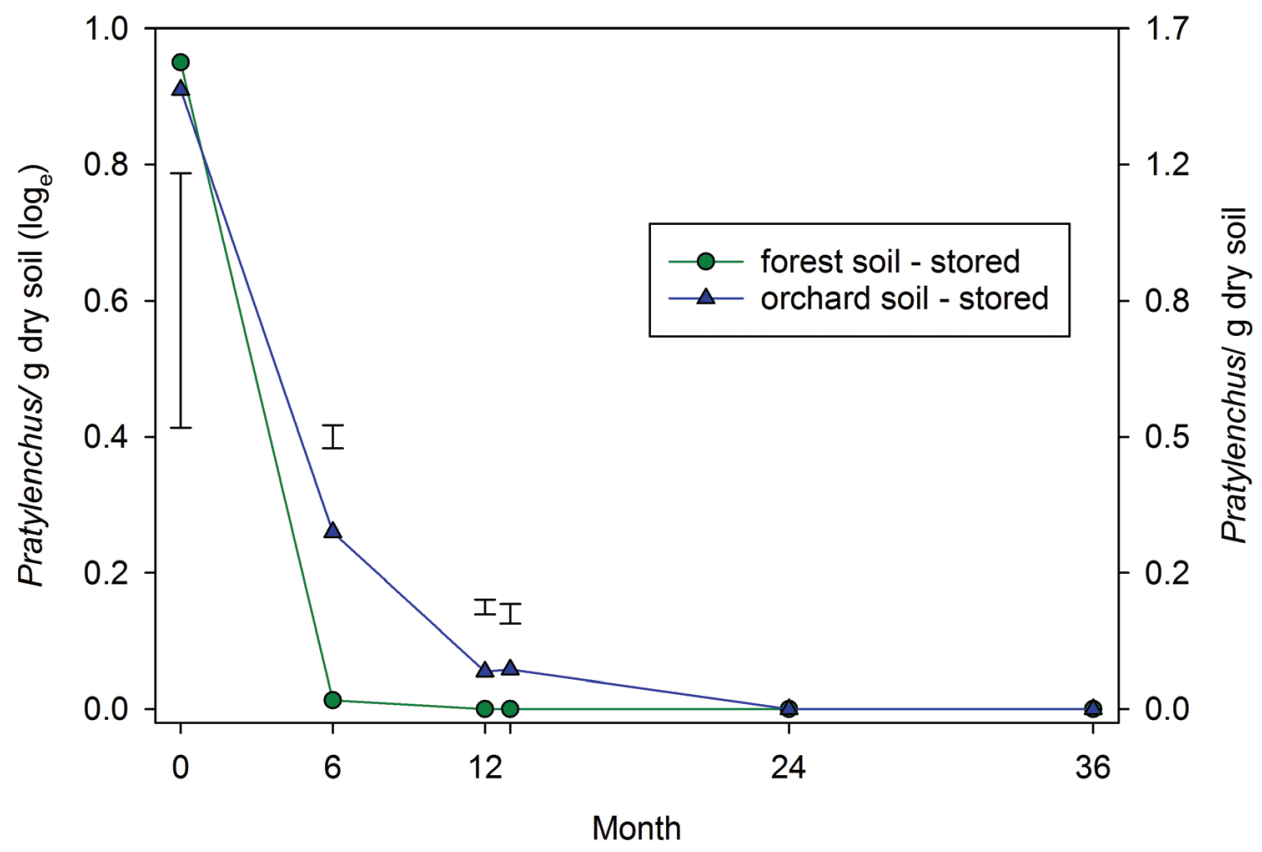

Figure 2. Pratylenchus per gram of dry soil ( $\log _{e}$ transformed) collected from either forest or orchard and stored in cupboards for 36 months. Error bars are SEDs. Note: transformed data presented with backtransformed scale on right hand side for ease of conversion to actual numbers /g.

\section{Molecular identification of PPNs}

The Pratylenchus DNA sequences from the forest soil matched P. bolivianus from the NCBI database and specimens were preserved to be confirmed morphologically. Pratylenchus sequences from the orchard soil indicated the presence of at least four species: P. crenatus, P. thornei, P. penetrans, and an unidentified Pratylenchus that had a poor match to Pratylenchus currently in the database (Table 3).

Specimens found in the orchard soil at the start of the experiment were most commonly $P$. penetrans with the unknown Pratylenchus sp. also being isolated, while $P$. crenatus and $P$. thornei were only isolated once the soil had begun to desiccate (Table 4). Specimens of $P$. crenatus were isolated at six and 13 months after storage but not from the 36 month samples. P. thornei, along with the unidentified Pratylenchus sp., were isolated at 12 and 36 months post storage.

When comparing the number of Pratylenchus present in the roots of white clover grown in fresh soil collected from the two original sampling sites, there was a significant difference between the two locations at 13 months $(P=0.004), 24$ and 36 months (both $\mathrm{P}<0.001$ ). For ryegrass, the number of Pratylenchus present in the roots grown in fresh soil was significantly different $(\mathrm{P}<0.001)$, at all three sample times.

Fewer Pratylenchus were found in the white clover grown in the fresh forest soil samples with a mean, median and range of 5.2, 4 and 1-17, compared to the fresh orchard soil (130.7, 144 and 39-224, respectively). 
Table 3. Pratylenchus specimens isolated and identified from orchard and forest soil using the closest matching BLAST reference (accessed August 2016).

\begin{tabular}{l|c|c|c}
\hline \multicolumn{1}{c|}{ Pratylenchus species $^{\text {bolivianus }}{ }^{2}$} & Soil source & BLAST reference & Match \\
\hline crenatus $^{\text {penetrans }}$ & forest & KP780256 & $99.9 \%$ \\
\hline thornei & orchard & KM580535 & $99.5 \%$ \\
\hline unidentified sp. & orchard & JX046990 & $99.9 \%$ \\
\hline
\end{tabular}

${ }^{a}$ to be confirmed morphologically

Table 4. Pratylenchus species extracted from orchard soil stored in cupboards and identified using D2/D3 primers for the $28 \mathrm{~S}$ gene of rDNA.

\begin{tabular}{l|c|c|c|c|c}
\hline \multirow{2}{*}{\multicolumn{1}{c|}{ Species }} & \multicolumn{5}{c}{ Months } \\
\cline { 2 - 6 } & $\mathbf{3}$ & $\mathbf{6}$ & $\mathbf{1 2}$ and $\mathbf{1 3}$ & $\mathbf{2 4}$ & $\mathbf{3 6}$ \\
\hline P. penetrans & Present & Present & & & \\
\hline P. crenatus & & Present & Present & & \\
\hline P. thornei & & Present & Present & & Present $^{\mathrm{a}}$ \\
\hline Pratylenchus sp. & & Present & Present & & Present $^{\mathrm{a}}$ \\
\hline
\end{tabular}

a five day extraction process

Table 5. Plant parasitic nematodes (excluding Pratylenchus spp.) isolated and identified from orchard and forest soil using the closest matching BLAST reference (accessed Aug 2016).

\begin{tabular}{l|c|c|c}
\hline \multicolumn{1}{c|}{ Plant parasitic nematode } & Soil origin & BLAST reference & Match \\
\hline Mesocriconema xenoplax & forest & KJ934180 & $96.3 \%$ \\
\hline Rotylenchus conicaudatus & forest & HQ700698 & $93.8 \%$ \\
\hline Globodera zelandica & forest & HQ260411 & $99.5 \%$ \\
\hline Paratylenchus leptos & forest & KR270602 & $87 \%$ \\
\hline Paratylenchus nanus & orchard & KF242196 & $100 \%$ \\
\hline Heterodera trifoli ${ }^{2}$ & orchard & LC030417 & $99.2 \%$ \\
\hline
\end{tabular}

${ }^{a}$ DNA sequencing did not give a distinction between $H$. trifolii, $H$. schachtii and $H$. betae.

Similar results were obtained for ryegrass growing in forest soil with a mean, median and range of $0.7,0.5$ and $0-3$, respectively. This compared to a mean, median and range of 135.4, 115.5 and 24-291, respectively for orchard soils. For freshly collected forest soil, more Pratylenchus were recovered using the misting method than the baiting method.

For the forest soil, with the exception of Globodera zelandica, the PPNs were a poor match to the sequences found in the NCBI website (Table 5). Morphological and molecular identification found that the spiral nematodes observed in the samples were a mixed population consisting of both Helicotylenchus and Rotylenchus species. No Helicotylenchus specimens were sequenced. 
For the Heterodera nematode extracted from the orchard soil, the DNA sequence did not give a clear distinction between $H$. trifolii, $H$. schachtii and $H$. betae. The sequence was compared to three reference sequences from NCBI of each species analysed in Geneious ${ }^{\mathrm{TM}}$ using the restriction site $M s p$ I. It produced a similar profile to $H$. trifolii and $H$. betae but not $H$. schachtii.

\section{Discussion}

This study has confirmed the hypothesis that not only are Pratylenchus species able to survive soil desiccation, but after prolonged storage are able to successfully reproduce on host plants.

The ability of nematodes to survive desiccation has been known for some time (Norton 1978). Nematodes that can achieve anhydrobiosis have been divided into two groups, slow-dehydration and fast-dehydration strategists (Womersley 1987). The majority of nematodes require a slow, controlled rate of water loss to achieve anhydrobiosis (Womersley et al. 1998). The soil in this study was stored in cupboards reducing air flow over the samples slowing the rate of desiccation, allowing any nematodes present that had the ability to survive water deficits to achieve anhydrobiosis. The survival of PPNs was greater in soil stored in cupboards than soil stored in sea containers (McNeill et al. 2017).

Nematodes have developed a number of means by which they can survive desiccation, which include survival stages such as eggs, cysts, and dauer larvae (Womersley et al. 1998; Wharton 2002). Nematodes from Globodera and Heterodera genera form cysts which can allow them to survive in the soil for many years, and some cyst species will not hatch unless stimulated by host root diffusates (Turner and Rowe 2006). This could potentially be the case for the G. zelandica and Heterodera juveniles that were extracted from the forest and orchard soil respectively that had been stored for three months. The other PPNs observed in this study, Paratylenchus, Helicotylenchus, Rotylenchus and Criconematidae also showed an ability to survive in stored soil albeit for a shorter period of time than Pratylenchus. Species from each of these genera have been found in previous studies to survive desiccation (Norton 1978). Other methods employed to slow the rate of water loss may include remaining in senescing plant tissue, swarming or forming aggregates and coiling (Womersley et al. 1998). Coiling has been observed in P. penetrans (Townshend 1984) and P. thornei (Glazer and Orion 1983). The soil in this current study included root fragments so it is possible they were a source of Pratylenchus nematodes able to withstand desiccation.

Pratylenchus species including $P$. penetrans and $P$. thorne $i$ have been recorded exhibiting anhydrobiosis (Glazer and Orion 1981; Townshend 1984; Townshend 1987; Anon 1997; Talavera et al. 1998; Ghaderi and Bideh 2011), but there is less information on the ability of $P$. crenatus to survive desiccation. Interestingly, Pratylenchus crenatus has been isolated from small quantities of soil associated with imported seed (Lal and Lal 2006). Survival of $P$. penetrans and $P$. thornei in air dried soil for up to 11 months has been pre- 
viously recorded and listed in a review by Norton (1978). Talavera et al. (1998) found $P$. thornei was able to penetrate roots after 75 days of desiccation. The current study isolated $P$. thornei from soil stored in a cupboard for 36 months (1097 days), but as an unidentified Pratylenchus species was also found after 36 months of storage, it is unclear which of the two species infected perennial ryegrass roots in the "baiting" experiment. Townshend (1984) found P. penetrans in slowly dried soil could survive up to 770 days (25.3 months) and that their infectivity and reproduction at 207 days was not affected by anhydrobiosis. The current study did not however find $P$. penetrans in the soil beyond six months (180 days). Conversely, P. crenatus was detected in soil that had been stored for 13 months but not at 24 or 36 months. Of the known Pratylenchus species identified from this study all three have a broad host range, particularly P. penetrans (Castillo and Vovlas 2007; Singh et al. 2013). However, Lolium perenne and L. multiflorum are considered less favourable hosts (Kimpinski et al. 1984; Townshend et al. 1984) than legumes such as red (Trifolium pratense L.) (Willis et al. 1982; Kimpinski et al. 1984) or white clover (T. repens L.) (L. Aalders, unpublished data). The plant host preference of the unidentified Pratylenchus species isolated from the orchard soil has yet to be determined.

The Pratylenchus isolated from the forest soils and tentatively identified as $P$. bolivianus, was only detected up to six months. Both white clover and ryegrass proved to be unfavourable hosts for this Pratylenchus sp. with root infection rates considerably lower than numbers extracted from soil using the misting technique.

Pratylenchus crenatus, P. penetrans and $P$. thornei are each regulated pests for at least one country globally (Singh et al. 2013), and this study has shown that $P$. crenatus and an unidentified species of Pratylenchus, along with $P$. penetrans and $P$. thornei, can also survive prolonged periods of desiccation. According to a review by Jones et al. (2013), Pratylenchus are ranked third only to Meloidogyne and Heteroderidae (includes Globodera and Heterodera) nematodes as having the greatest impact on crops worldwide, and coupled with their ability to survive desiccation their status as a biosecurity risk is increased with more than 80 Pratylenchus species described (Siddiqi 2000).

The study showed that for disturbed soil stored in protected environments Pratylenchus nematode populations can survive prolonged storage for up to 36 months (1095 days) and that in the presence of a suitable host plant, 'baiting' was a more sensitive technique in detecting Pratylenchus spp. than the misting extraction technique. However, this study demonstrated that the approach only works if a suitable host plant is available. Without a priori knowledge of the PPN-plant host association, plant baiting may also produce false negatives. For other PPN, the lack of a suitable host plant meant that the mistifier extraction method was more accurate. Where the host plant was not known, this provided the best option to assess presence /absence, although this method may not extract cyst nematodes. Extraction using flotation /sugar centrifugation would have extracted cysts as well as vermiform stages but the technique was not feasible with the high numbers of soil samples. Furthermore, examining only the roots of bait plants for parasitic nematodes will only show those endo-parasitic species present, it cannot be used to assess external root feeding species, which would require that the soil surrounding bait plants is also checked. 
In the context of plant biosecurity and providing an accurate risk assessment for soil contaminants, the development of a generic test for PPN that induces nematodes in a resting stage to emerge and respond to a cue would enhance the probability of detection. Having a better understanding of PPN survival in soil inadvertently transported with commodities, freight, used machinery or humans (e.g. footwear) is important in the development of both scientifically valid pest risk analysis as well as cost-effective management strategies (Colunga-Garcia et al. 2013, Singh et al. 2015, McNeill et al. 2017).

\section{Conflict of interest statement}

The authors declare that the research was conducted in the absence of any commercial or financial relationships that could be construed as a potential conflict of interest.

\section{Authors contribution}

LA: Developed the research concept, led and carried out the extraction and identification of nematodes, contributed to manuscript writing. MM: Developed the research concept, carried out the soil sampling and contributed to manuscript writing, NB: Contributed to development of baiting technique, identification of nematodes and writing of the manuscript. CC: Analyzed data.

\section{Acknowledgements}

The research was funded by AgResearch via the Better Border Biosecurity research collaboration (www.b3nz.org). The authors thank Dr Barbara Barratt, Dr Scott Hardwick, Dr Alison Popay and Dr Michael Wilson (AgResearch) for reviewing the draft document.

\section{References}

Aalders LT, James TK, McNeill MR (2012) Excavators and dirt: assessing the quarantine risk posed by nematodes and seeds. New Zealand Plant Protection 65: 298 (poster abstract).

Bell NL, Watson RN (2001) Optimising the Whitehead and Hemming tray method to extract plant parasitic and other nematodes from two soils under pasture. Nematology 3: 179-185. https://doi.org/10.1163/156854101750236312

Blaxter ML, De Ley P, Garey JR, Liu LX, Scheldeman P, Vierstraete A, Vanfleteren JR, Mackey LY, Dorris M, Frisse LM, Vida JT, Thomas WK (1998) A molecular evolutionary framework for the phylum Nematoda. Nature 392: 7175. https://doi.org/10.1038/32160

Castillo P, Vovlas N (2007) Pratylenchus (Nematoda: Pratylenchidae): Diagnosis, Biology, Pathogenicity and Management. Brill. https://doi.org/10.1163/ej.9789004155640.i-523 
Colunga-Garcia M, Haack RA, Magarey RD, Borchert DM (2013) Understanding trade pathways to target biosecurity surveillance. NeoBiota 18: 103-118. https://doi.org/10.3897/ neobiota.18.4019

De Ley P, Felix M-A, Frisse LM, Nadler SA, Sternberg PW, Thomas WK (1999) Molecular and morphological characterisation of two reproductively isolated species with mirror-image anatomy (Nematoda: Cephalobidae). Nematology 1: 591-612. https://doi. org/10.1163/156854199508559

Decraemer W, Hunt DJ (2006) Structure and Classification. In: Perry RNMM (Ed.) Plant Nematology. CABI PUBLISHING-C A B INT, Cabi Publishing, Wallingford 0x10 8de, Oxon, UK, 3-32. https://doi.org/10.1079/9781845930561.0003

Gadgil PD, Bulman LS, Crabtree R, Watson RN, O’Neil JC, Glassey KL (2000) Significance to New Zealand forestry of contaminants on the external surfaces of shipping containers. New Zealand Journal of Forestry Science 30: 341-358.

Ghaderi R, Bideh AK (2011) The effect of water stress on the survival of common cereal rootlesion nematodes (Pratylenchus neglectus and P. thornei), under laboratory, greenhouse, microplats and field conditions. Iranian Journal of Plant Pathology 47: e165-Pe177.

Glazer I, Orion D (1981) Anhydrobiosis a summer survival mechanism of Pratylenchus thornei. Nematropica 11: 82-83.

Glazer I, Orion D (1983) Studies on Anhydrobiosis of Pratylenchus thornei. Journal of Nematology 15: 333-338.

Hooper DJ (1986) Extraction of free-living stages from soil. In: Southey JF (Ed.) Laboratory methods for work with plant and soil nematodes. H M S O Books, Norwich, NR3 1PD, Norfolk, 5-30.

Hooper DJ, Evans K (1993) Extraction, identification and control of plant parasitic nematodes. In: Evans K, Trudgill DL, WJ M (Eds) Plant parasitic nematodes in temperate agriculture. CAB International, Wallingford, England, 1-59.

Hughes KA, Convey P, Maslen NR, Smith RIL (2010) Accidental transfer of nonnative soil organisms into Antarctica on construction vehicles. Biological Invasions 12: 875-891. https://doi.org/10.1007/s10530-009-9508-2

Hulme PE (2014) An Introduction to Plant Biosecurity: Past, Present and Future. In: Gordh G, McKirdy S (Eds) The Handbook of Plant Biosecurity. Springer Netherlands, 1-25. https:// doi.org/10.1007/978-94-007-7365-3_1

Hunt DJ, De Ley P (1996) Nematodes in soils. In: Hall GS (Ed.) Methods for the examination of organismal diversity in soils and sediments. CAB International, Wallingford, UK, 227-240.

Jones JT, Haegeman A, Danchin EGJ, Gaur HS, Helder J, Jones MGK, Kikuchi T, ManzanillaLópez R, Palomares-Rius JE, Wesemael WML, Perry RN (2013) Top 10 plant-parasitic nematodes in molecular plant pathology. Molecular Plant Pathology 14: 946-961. https:// doi.org/10.1111/mpp.12057

Joyce SA, Burnell AM, Powers TO (1994) Characterization of Heterorhabditis isolates by PCR amplification of segments of mtDNA and rDNA genes. Journal of Nematology 26: 260-270.

Kearse M, Moir R, Wilson A, Stones-Havas S, Cheung M, Sturrock S, Buxton S, Cooper A, Markowitz S, Duran C, Thierer T, Ashton B, Mentjies P, Drummond A (2012) Geneious 
Basic: an integrated and extendable desktop software platform for the organization and analysis of sequence data. Bioinformatics 28: 1647-1649. https://doi.org/10.1093/bioinformatics/bts199

Kimpinski J, Kunelius HT, Willis CB (1984) Plant Parasitic Nematodes in Temperate Forage Grass and Legume Species in Prince-Edward Island Canada. Canadian Journal of Plant Pathology 6: 160-164. https://doi.org/10.1080/07060668409501577

Lal R, Lal A (2006) Plant parasitic nematodes intercepted from seeds, soil clods and packing material under import quarantine. Journal of New Seeds 8: 49-60. https://doi.org/10.1300/ J153v08n01_04

Lee WG, Lee DE (2015) New Zealand - a land apart. In: Stow A, Maclean N, Holwell GI (Eds) Austral Ark. Cambridge University Press, Cambridge, UK, 24-44.

Mack RN, Simberloff D, Lonsdale WM, Evans H, Clout M, Bazzaz FA (2000) Biotic invasions: causes, epidemiology, global consequences, and control. Ecological Applications 10: 689-710. http://dx.doi.org/10.1890/1051-0761(2000)010[0689:BICEGC]2.0.CO;2

McNeill M, Phillips C, Young S, Shah F, Aalders L, Bell N, Gerard E, Littlejohn R (2011) Transportation of nonindigenous species via soil on international aircraft passengers' footwear. Biological Invasions 13: 2799-2815. https://doi.org/10.1007/s10530-011-9964-3

McNeill MR, Phillips CB, Robinson AP, Aalders L, Richards N, Young S, Dowsett C, James T, Bell N (2017) Defining the biosecurity risk posed by transported soil: Effects of storage time and environmental exposure on survival of soil biota. Neobiota 32: 65-88. https:// doi.org/10.3897/neobiota.32.9784

McSorley R, Walter DE (1991) Comparison of soil extraction methods for nematodes and microarthropods. Agriculture, Ecosystems \& Environment 34: 201-207. doi:http://dx.doi. org/10.1016/0167-8809(91)90106-8

Norton DC (1978) Ecology of Plant-Parastic Nematodes. JohnWiley and Sons, New York, $268 \mathrm{pp}$.

Barker KR (1997) Opportunities for integrated management of plant-parasitic nematodes in the Near East. http://www.fao.org/docrep/V9978E/v9978e0c.htm [accessed]

Pimentel D, Lach L, Zuniga R, Morrison D (2000) Environmental and economic costs of nonindigenous species in the United States. Bioscience 50: 53-65. http://dx.doi. org/10.1641/0006-3568(2000)050[0053:EAECON]2.3.CO;2

Rohan TC, Bell NL, Lee NDF, Aalders LT (2006) Efficacy of root digestion and maceration in determining abundance of root-inhabiting nematodes. New Zealand Plant Protection 59: 166-171.

Said A, Subbotin SA, Moens M (2002) Identification of the beet cyst nematode Heterodera schachtii by PCR. European Journal of Plant Pathology 108: 497506

Siddiqi MR (2000) Tylenchida: parasites of plants and insects. (Ed 2) CABI Publishing, Wallingford, xvii + 833 pp. http://dx.doi.org/10.1079/9780851992020.0000

Singh SK, Ash GJ, Hodda M (2015) Keeping 'one step ahead' of invasive species: using an integrated framework to screen and target species for detailed biosecurity risk assessment. Biological Invasions 17: 1069-1086. https://doi.org/10.1007/s10530-014-0776-0

Talavera M, Valor H, Tobar A (1998) Post-anhydrobiotic viability of Pratylenchus thornei and Merlinius brevidens. Phytoparasitica 26: 293-299. https://doi.org/10.1007/BF02981443 
Tenente RCV, Manso ESC, Mendes MAS, Marques ASAd, Filho EF (1996) Quarantine detection of nematodes and procedures for their eradication from vegetatively propagated materials imported by Brazil. Nematropica 26: 187191.

Townshend JL (1984) Anhydrobiosis in Pratylenchus penetrans. Journal of Nematology 16: 282-289. https://doi.org/10.4141/cjps84-050

Townshend JL (1987) Anhydrobiosis in Pratylenchus penetrans and Tylenchorhynchus new species in cultivated soils cropped to winter rye. Journal of Nematology 19: 164-171.

Townshend JL, Cline RA, Dirks VA, Marks CF (1984) Assessment of turfgrasses for the management of Pratylenchus penetrans and Paratylenchus projectus in orchards. Canadian Journal of Plant Science 64: 355-360.

Turner SJ, Rowe JA (2006) Cyst nematodes. In: Perry RN, Moens M (Eds) Plant Nematology. CABI Publishing, UK, 910-112. https://doi.org/10.1079/9781845930561.0091

Wharton DA (2002) Nematode Survival Strategies. In: Lee DL (Ed) The Biology of Nematodes. CRC Press, 389-412. https://doi.org/10.1201/b12614-17

Willis CB, Kimpinski J, Thompson LS (1982) Reproduction of Pratylenchus crenatus and P. penetrans on forage legumes and grasses and effect on forage yield. Canadian Journal of Plant Pathology 4: 169-174. https://doi.org/10.1080/07060668209501320

Womersley C (1987) A reevaluation of strategies employed by nematode anhydrobiotes in relation to their natural environment. Vistas on Nematology: A Commemoration of the Twenty-fifth Anniversary of the Society of Nematologists; 1987:89 ref. Society of Nematologists, Inc, Hyattsville, Maryland, 165-173.

Womersley CZ, Wharton DA, Higa LM (1998) Survival biology. In: Perry RN, Wright DJ (Eds) The physiology and biochemistry of free living and plant parasitic nematodes. CABI Publishing, Wallingford \& New York, 271-302.

Work TT, McCullough DG, Cavey JF, Komsa R (2005) Arrival rate of nonindigenous insect species into the United States through foreign trade. Biological Invasions 7: 323-332. http://dx.doi.org/10.1007/s10530-004-1663-x 